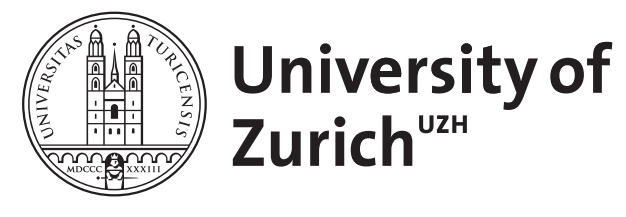

\title{
Lepra vulgaris. History of Psoriasis
}

\author{
Burg, G ; Geiges, M
}

\begin{abstract}
Background: The history of psoriasis, remains highly speculative for the time before Willan (1757-1812), and can be reliably assigned only for the last 200 years. Terms such as "Leprosy", "Impetigo" and "Psora" have been used in the centuries before. Hebra (1806-1880) gave a morphological and nosologic definition, in which also the histopathology appearance was taken into account. In the early 20th century, it was the biochemistry and histochemistry, which provided new insights. In the second half of the 20 th century, immunocytochemistry and immunology shed some light on the pathogenetic processes of the disease. At the end of the 20th and at the beginning of the 21st century, it is the triumph of genetics and immunology, which have opened new therapeutic possibilities due to the interesting insights into the pathogenesis of psoriasis. However besides the new therapeutic modalities, which harbor some health and some economic threats, classical approaches still remain valuable tools.
\end{abstract}

DOI: https://doi.org/10.6003/jtad.1483r1

Posted at the Zurich Open Repository and Archive, University of Zurich

ZORA URL: https://doi.org/10.5167/uzh-108718

Journal Article

Published Version

Originally published at:

Burg, G; Geiges, M (2014). Lepra vulgaris. History of Psoriasis. Journal of the Turkish Academy of Dermatology, 8(3):1483r1.

DOI: https://doi.org/10.6003/jtad.1483r1 


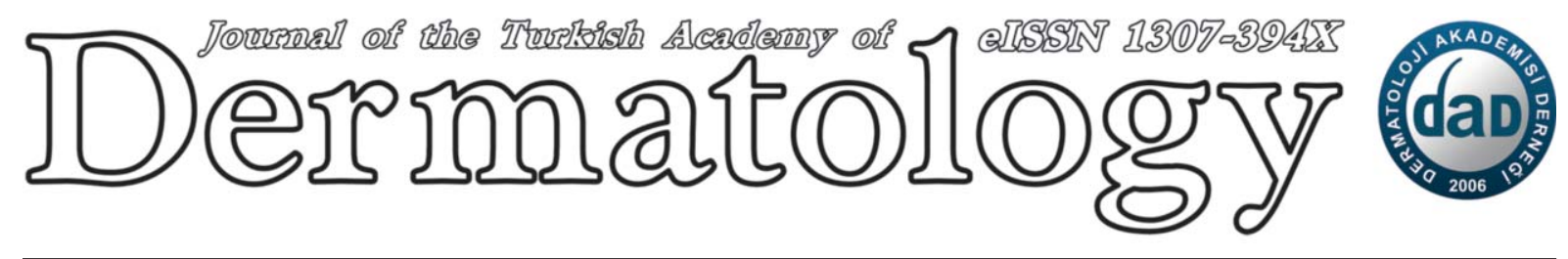

Review

DOI: 10.6003/jtad.1483r1

\title{
Lepra vulgaris. History of Psoriasis
}

\author{
Günter Burg, MD, Michael Geiges, MD
}

Address: *Department of Dermatology University Hospital Zurich, Institute for the History of Medicine University of Zurich, Hautarztpraxis, 8303 Kloten / Zurich, Marktgasse 3

E-mail: g.burg@access.uzh.ch

*Corresponding Author: Dr Guenter Burg, Prof \& Chairm. emer. CH 8124 Maur/Zürich Haldenstr. 14

Published:

J Turk Acad Dermatol 2014; 8 (3): 1483r1.

This article is available from: http://www.jtad.org/2014/3/jtad1483rl.pdf

Key Words: Psoriasis, history, lepra

\begin{abstract}
Background: The history of psoriasis, remains highly speculative for the time before Willan (17571812), and can be reliably assigned only for the last 200 years. Terms such as "Leprosy", "Impetigo" and "Psora" have been used in the centuries before. Hebra (1806-1880) gave a morphological and nosologic definition, in which also the histopathology appearance was taken into account. In the early 20th century, it was the biochemistry and histochemistry, which provided new insights. In the second half of the 20th century, immunocytochemistry and immunology shed some light on the pathogenetic processes of the disease. At the end of the 20th and at the beginning of the 21 st century, it is the triumph of genetics and immunology, which have opened new therapeutic possibilities due to the interesting insights into the pathogenesis of psoriasis. However besides the new therapeutic modalities, which harbor some health and some economic threats, classical approaches still remain valuable tools.
\end{abstract}

\section{Introduction}

Psoriasis is one of the most common diagnoses in dermatology; therefore it is justified to provide some information on the historical background of this frequent disease.

One has to admit however, that talking about historical aspects of diseases and especially of dermatoses is always somehow speculative. It is clear, that most of the diseases we see today already existed 2000 and more years ago and one has to be aware of the fact, that legends and mystery easily melt into "history". The perception of the diseases in ancient time was rather religious or mysterious than scientific, as we see it today.
Much has been written about the history of psoriasis, which roughly can be divided into 3 periods, looking back 2000 years, 200 years and to the past 20 years.

The following citations characterize the challenge, which psoriasis imposed and still does on physicians and patients: William James Erasmus Wilson (1809 - 1884) stated "...it is not a disease, on which to build a medical reputation..." and Paul Bechet, New York (1936) pointed out that "Psoriasis is an antidot for dermatologists' ego. " (cited from [1])

There are several reviews, on the subject, which have been a major resource for this review article $[2,3,4,5,6,7]$. 


\section{Ancient Times: Egypt, Greece and Rome}

In Ancient Times diseases were deemed an individual punishment for blasphemic conduct of life or a consequence of low sanitation and hygiene. "Psoriasis" at that time like other diseases was an issue of ignorance, confusion of nomenclature and terminology

When looking 2 or 3'000 years back, religious texts sometimes may give interesting views or at least some arguments for speculations.

In one of the most famous documents conserved today, the Ebers Papyrus (around 1500 BC), do not mention Psoriasis but give some remedies for treating skin diseases in general.

Hippocrates (460-370 BC) refers to "impetigo" without specific mentioning of psoriasis even though he must have seen the disease.

Aulus Cornelius Celsus (25BC-50 AD), who probably was not a physician, but a roman enzyclopedian, in his "De Re Medica Libri Octo" describes psoriasis, but calls it "impetigo".

The "Corpus Galenicum" was the basis for teaching and learning medicine over centuries. Galen (133-200) introduced the term "psoriasis" to designate diseases (scaling of eyelids and scrotum with erosions; seborrhoeic eczema?), entirely different from psoriasis.

\section{Medieval Ages from $6^{\text {th }}$ till $15^{\text {th }}$ Century}

In the Medieval Ages (600 - 1500 AC), Avicenna (Ibn Sina) (980-1037) - a Persian physician, physicist, scientist and philosopherwas the most influential representative of Medieval medicine. His encyclopaedic Canon of Medicine, completed in 1025, comprises five books compiling the medical knowledge of the time. It is considered one of the most famous books in the history of medicine and it provided the basis for teaching and learning medicine not only in the orient but also in Europe. It also contains the first careful description of skin diseases. Avicenna very much followed Galen.

Hildegard von Bingen (1098 - 1179) was a insubordinate Abbess and polymath (music, natural sciences, medicine, theology). She used to pass out if she wanted to pursue her aims against the opposition of the authorities. The medical treatise ascribed to Hildegard were Causae et Curae (causes and treatments) and Physica, in which she compiles the folk and monastic medicine of her time using herbs, stones and animals on the principle of contraries (contraria contrariis curantur) for the treatment of diseases [8].

She differentiates various types of "Lepra" (skin rashes, most probably including "psoriasis") caused either due to acoria and drunkenness or due to irascibility and "Lepra contagiosa sanabilis" due to lasciviousness.

The first universities and medical schools were founded in Europe in Salerno, Bologna, Montpellier, Paris and Oxford in the $12^{\text {th }}$ and $13^{\text {th }}$ century. Little attention was attributed to changes of the skin, which still at that time in the context of "humoral medicine" were thought to be just an "excretion organ" rather than the manifestation of diseases. Paintings from that time do not show specific skin lesions but just dots and spots on or within the skin

In "De morbis cutaneis, et omnibus corporis humani excrementis tractatus locupletissimi" (Venedig 1572) Girolomo Hironymus Mercurialis (1530-1606) classifies diseases of the skin according to their localisation [1] in the head and neck or [2] at other sides of the body. He paid little attention to morphology of the single lesions and described psoriasis under the name of "lepra grecorum" and for other conditions used the term "psora"(itch) [9].

The first ones to look for morphology of skin changes and probably showing psoriasis for the first time were artists, like Ferdinand Bol, a flamish painter, who in his work "The Director of the Lepra House in Amsterdam" depicted the social situation of a young boy showing his capillitium covered with dense white scales, which from a medical point of view today might be interpreted as psoriasis or rather as Favus (Figure 1) [10].

In summary, in the Middle Ages there was no scientific pathogenetic or morphologic perception of the disease, we refer to today as psoriasis and we should be cautious in overinterpreting descriptions from this time. 


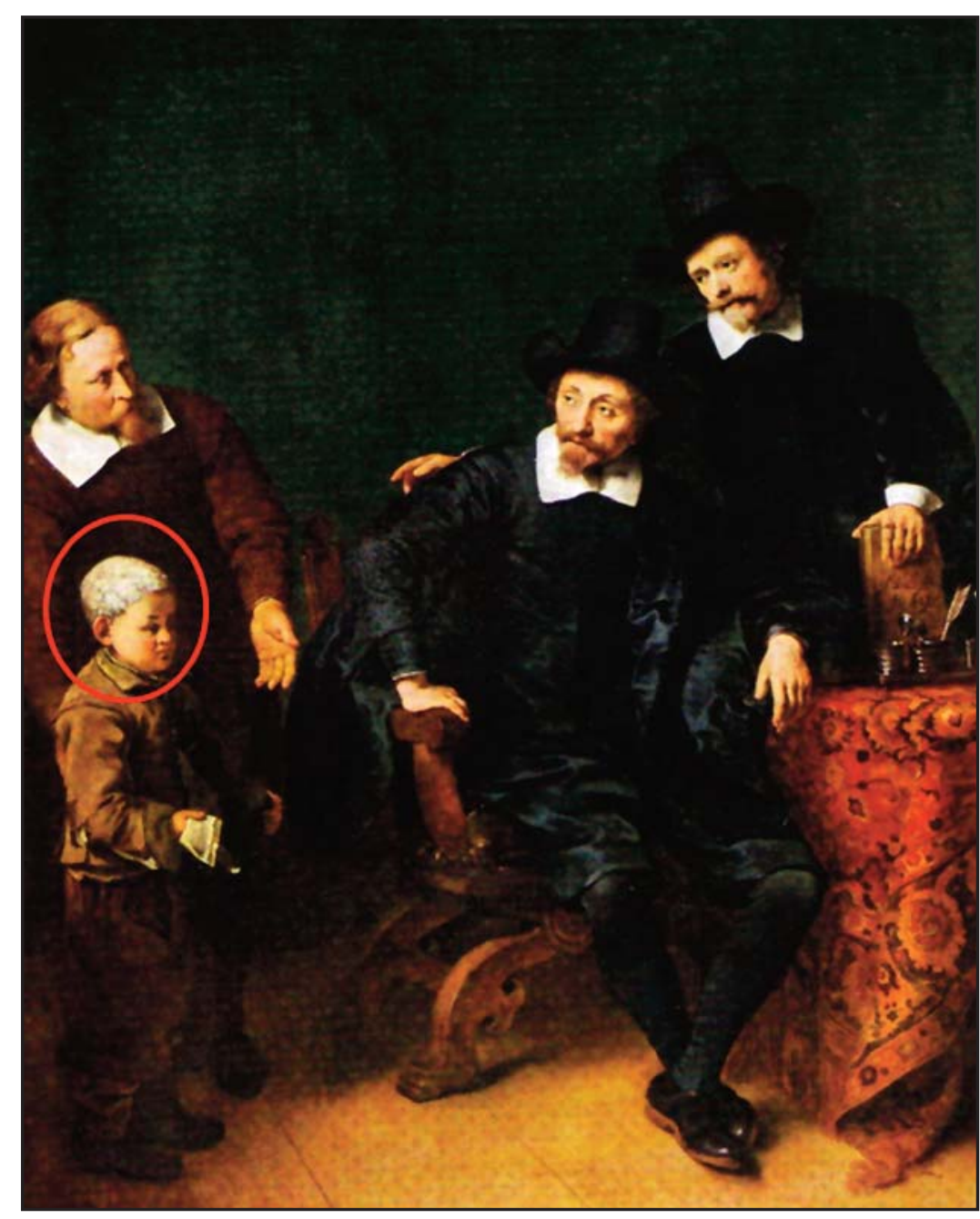

Figure 1. Ferdinand Bol (16161680). The Director of the LepraHouse in Amsterdam. Le Petit Palais, Paris. Lepra or Favus on the capillitium of a young boy
The Beginning of Academic Dermatology in the $18^{\text {th }}$ Century

Josef Plenck (1735-1807), was an Austrian surgeon and obstetrician. In his book "Doctrina de Morbis Cutaneiis" (1776) [11] he classified 120 skin diseases into 14 classes based on the works of Carl von Linné (1707-1778) and Francois Boissier de Sauvages de la Lacroix (1707-1767). Some remarks in Class VI: Lepra crustosa and in Class VII about squamous diseases might refer to psoriasis, [11]

Robert Willan's (1757-1812) [12] improved the classification of skin disorders based on morphologic criteria of Joseph Jakob Plenck (1735-1807) [11]. The second of the 8 classes in his treatise dealt with "Scales" (Figure 2). He differentiated psoriasis from leprosy (psora leprosa and lepra grecorum) and described different forms of psoriasis: guttata, diffusa, gyrata, palmaria, unguium, inveterata. He also noticed that the disease begins on the knees and elbows, attacks the scalp and also the finger and toe-nails [9]. In his book there we find the first medical painting of lepra vulgaris that can be identified as psoriasis. (Quelle: Willan, Robert: "Description and Treatment of Cutaneous Diseases" Order I. papulous eruptions, London 1798)

Charles Anne Lorry (1726-1783) was a contemporary of Willan and a physician of Louis XVI. In his book "Tractatus de morbis cutaneis" he presents an etiologic classification of dermatoses, mentioning also a phenomenon, later described by Carl Heinrich Auspitz (1835-1886) [13].

Another contemporarian of Willan, was Baron Jean Loius Alibert (1768-1837) in Paris. He tried to consider morphologic, pathogenetic, metabolic and other aspects in order to create a systemic, kind of pattern-organization of diseases of the skin. However the result, the "Arbre de Diagnoses" generated a big confu- 


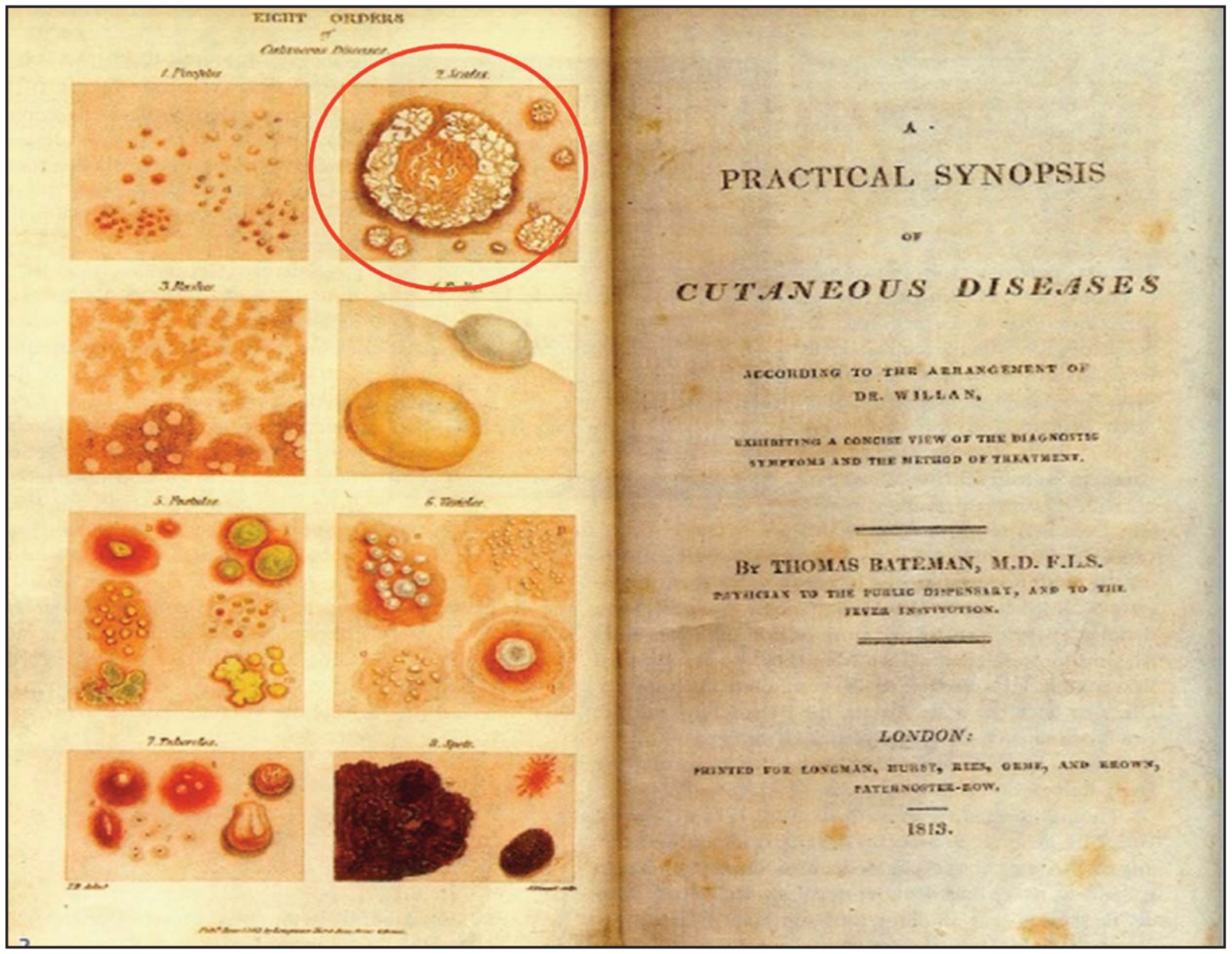

Figure 2. Willan, R. and T. Bateman (1813). A Practical Synopsis of Cutaneous Diseases. London. The second of the 8 classes dealt with "Scales"

sion, placing "psoriasis" as "dartre squameuse" besides other "dartres". Wilkinson (1822), an admirer of Willan commented Alibert's work with the following writing (cited acc to [14]): "From the perusal of Monsieur Alibert's inflated fustian in his 'Description des Maladies de la Peau' I rise, as I think every sober man must rise, puzzled and dis-

Table 1. Perception of "Psoriasis" through the Centuries

Ancient Hebrews (Old Testament)

Hippocrates

Celsus (25 BC-45 AD)

Galen (133-200 AD)

Medivial Ages/authors (500-1600)

Lorry and Plenck

Willan

Alibert

Gibert (1834)

Hebra (1841) "lepra" covers various dermatoses including, ichthyosis, elephantiasis (true lepra), vitiligo ("alphos"), eczema, syphilis(?) and psoriasis impetigo, no specific mentioning of "psoriasis" even though he must have seen the disease

first description of psoriasis as second species of "impetigo" introduced the term "psoriasis" to designate diseases (scaling of eyelids and scrotum with erosions; seborrhoeic eczema?), entirely different from psoriasis

No clinico-morphologic description. "Leprosy" -like in ancient times- covered various diseases

no accurate description or differentiation

first morphologic description after Celsus and differentiation between true leprosy and lepra vulgaris ("Psoriasis")

big confusion: names dartre sèche, dartre squameuse lichénoide and dartre furfuracée. Alibert" used the term psoride pustuleuse as a synonym for scabies

one year before Hebra had stated, that lepra vulgaris is just another form of psoriasis

eliminated the term "lepra" and gave a scientific conception to "psoriasis" 
gusted; ... he has continued ... to render this department of the science (Hôpital St. Louis in Paris) more confused and incomprehensible than he found it."

The following table summarizes the history of the perception of what today we refer to as psoriasis [Table 1]

Prior to Hebra, the skin was seen as a place for relief of bad fluids according to the concept of humoralism and skin disorders were not treated in order to let the bad fluids out.

Ferdinand Hebra (1816-1880) (Figure 3), who is deemed as the one of the "fathers" of dermatology as a self-standing discipline, was a surgeon. At the age of 29 he was appointed chairman of the department of Dermatology, which had been established by and for him. He confirmed the high reputation of the Vienna School for dermatology.

Hebra cut the Gordian knot and defined psoriasis as a distinct disease entity in 1841 . Hebra described many diseases and in self experiments proved scabies to be exclusively due to mites, which could be treated [15].

\section{Variants, Diagnostic Signs and Histopathology of Psoriasis}

In the Atlas on Skin Diseases edited by Pringle in 1897 [16]. Jacquet considers "psoriasis figurate" a special disease, related to Unna's seborrhoeic eczema and to be different from the psoriasis vulgaris, described and depicted by Feulard in the same atlas.

Von Zumbusch observed a male patient, who had had classic psoriasis for several years and finally developed multiple pustules [17, 18]. Andrews at the Annual Session of the American Medical Association in Milwaukee 1933 presented patients with pustular eruptions of the palms and soles and described fifteen cases [19], which had clinical features similar to the description of pustular psoriasis of the extremities, given by Barber [20].

Heinrich Köbner (1838-1904), who 1861 founded his own Institute for Dermato-Venereology in Breslau, presented a case in whom psoriatic lesions developed at the site of a bite by a horse (isomorphic reaction) $[\mathbf{2 1}, \mathbf{2 2}]$ (cit acc [23]). This observation initiated an intense academic discussion on the impact of

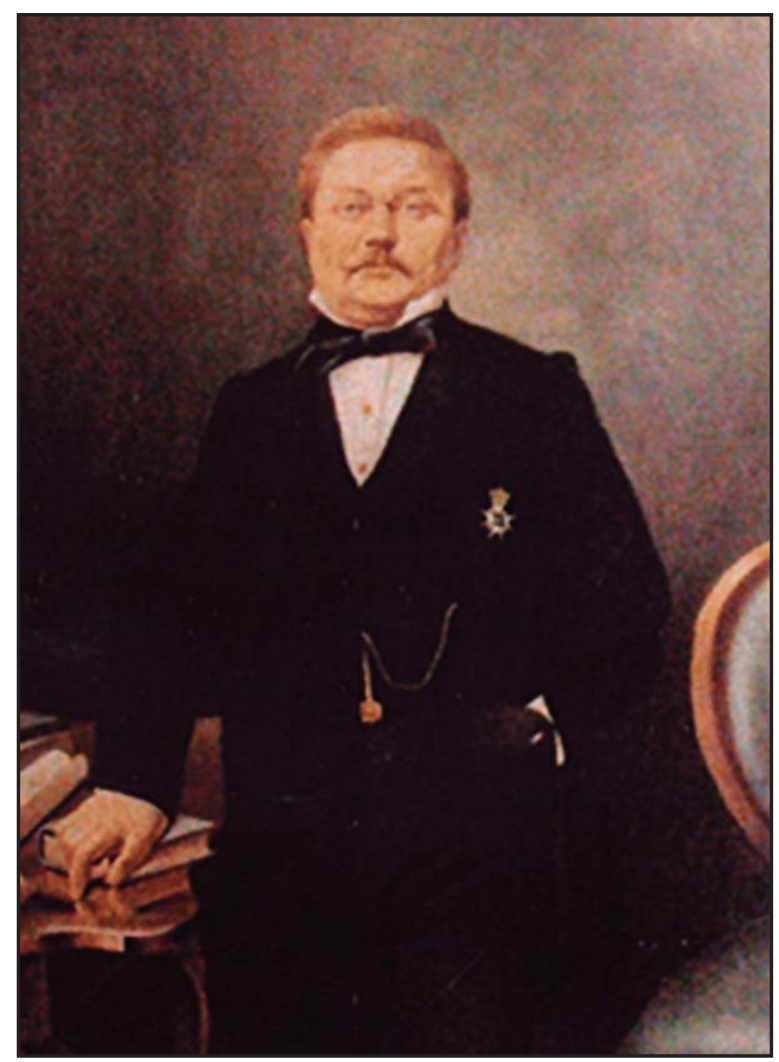

Figure 3. Ferdinand Hebra (1816-1880), the "Father of Dermatology"

external influences in the pathogenesis of psoriasis.

The histologic hallmarks of psoriasis [Table 2] are known for $>200$ years.

Carl Heinrich Auspitz (1835-1886) was an Austrian dermatologist. He described and explained the phenomenon, which is due to the small bridge of epidermis above the psoriatic papillae [9].

Paul Gerson Unna (1850-1929) was one of the first dermatopathologists. In his voluminous book in a brief chapter on psoriasis he describes the basic characteristics of the disease (parakeratosis, proliferation of the epidermis, and changes of vessels) [24].

The $19^{\text {th }}$ century was the time, when great progress in medicine came from great discoveries in microbiology: favus (Schönlein 1839), Lepra (Hansen 1872), gonorrhoea ( $\mathrm{Ne}$ isser 1879), Tbc (Koch 1892), chancre (Ducrey 1889), syphilis (Schaudinn and Hoffmann 1905). In speculating about the pathogenesis of psoriasis, Unna during his histopathologic studies observed "micrococci" and commented his findings as follows: "«...unfortunately 
Table 2. The Histologic Hallmarks of Psoriasis
* Epidermal hyperproliferation with loss of proper stratified differentiation of the affected epidermis (parakerato- sis)
* Expansion of the dermal vascular bed, elongation and tortuous dilatation of postcapillary venules in the st. pa- pillare
* Accumulation of (T-) lymphocytes and other inflammatory cells (dendritic cells/macrophages) in both the dermis and epidermis

the sparseness of the micrococci in the horny layer of psoriasis renders their identification not impossible but difficult...". Unna's observations however were critically questioned by other investigators $[\mathbf{2 5}, \mathbf{2 6}]$.

Another histopathologic hallmarks of psoriasis are the intraepidermal microabscesses and spongiform pustules, as described by the Australian physician William John Munro (1861-1908) in 1898 [27] (Figure 4) and Franjo Kogoj (1894-1983) from Zagreb in 1928 respectively.

Woronoff at the department of dermatology in Moscow described ring like anaemisation of the skin around lesions of psoriasis and secondary syphilis, which he called "pseudoatrophic zones" [28] (Figure 5).

\section{History of the Pathogenesis of Psoriasis}

Like in other diseases, pathogenetic concepts always have to be seen in the context of the medical knowledge of the time, and technologic and scientific progress [Table 3]. It therefore is not surprising, that a decease

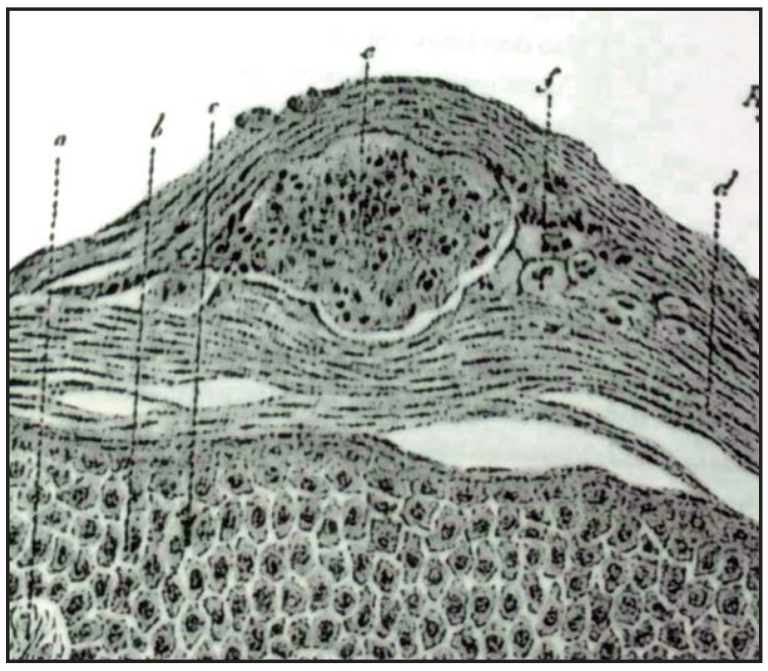

Figure 4. Microabscess as described by Munro in $1898[27]$ presenting with so many various clinical and morphologic features like psoriasis has been and still is a highly interesting issue for speculations as well as for solid clinical and laboratory investigations; even more since it got clear, that psoriasis is not just a disease of the skin but evolves on a systemic pathogenetic background.

A genetic background already has been assumed for a long time (Wutzdorf [29], Köbner, Hebra, cit acc [23]). More recent work has shown that there are at least 2 genetic constellations: (1) a juvenile exanthematic form and (2) an adult form which presents as large stable plaques $[\mathbf{3 0}, \mathbf{3 1}]$.

Because of the symmetry of the disease, Pringle and his contemporaries also thought of a pathogenetic impact of the nervous system [16].

A major breakthrough was the detection of the acceleration of the epidermal turnover by cytogenetic studies $[\mathbf{3 2}, \mathbf{3 3}]$.

Immunocytochemical studies in the 1970s showed the involvement of dermal dendritic cells (macrophages) [34]. and of prominent blood vessels in the papillary dermis [35].

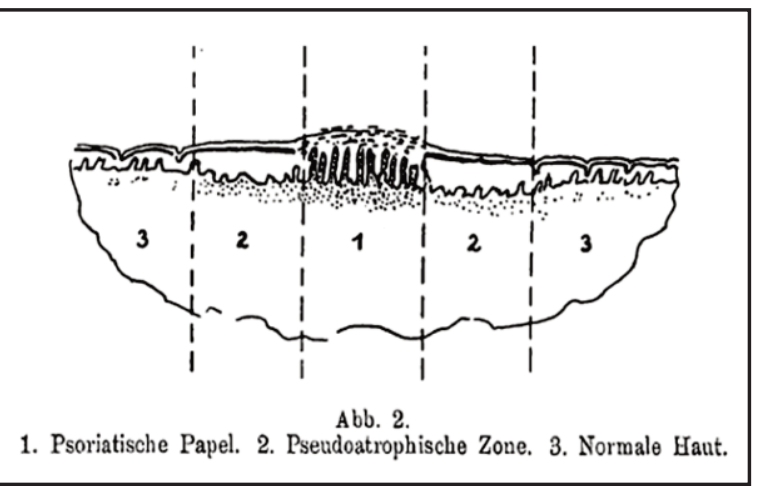

Figure 5. Woronoff-rings as schematically depicted in his original paper on his observation [28] 
Table 3. History of the Pathogenesis of Psoriasis

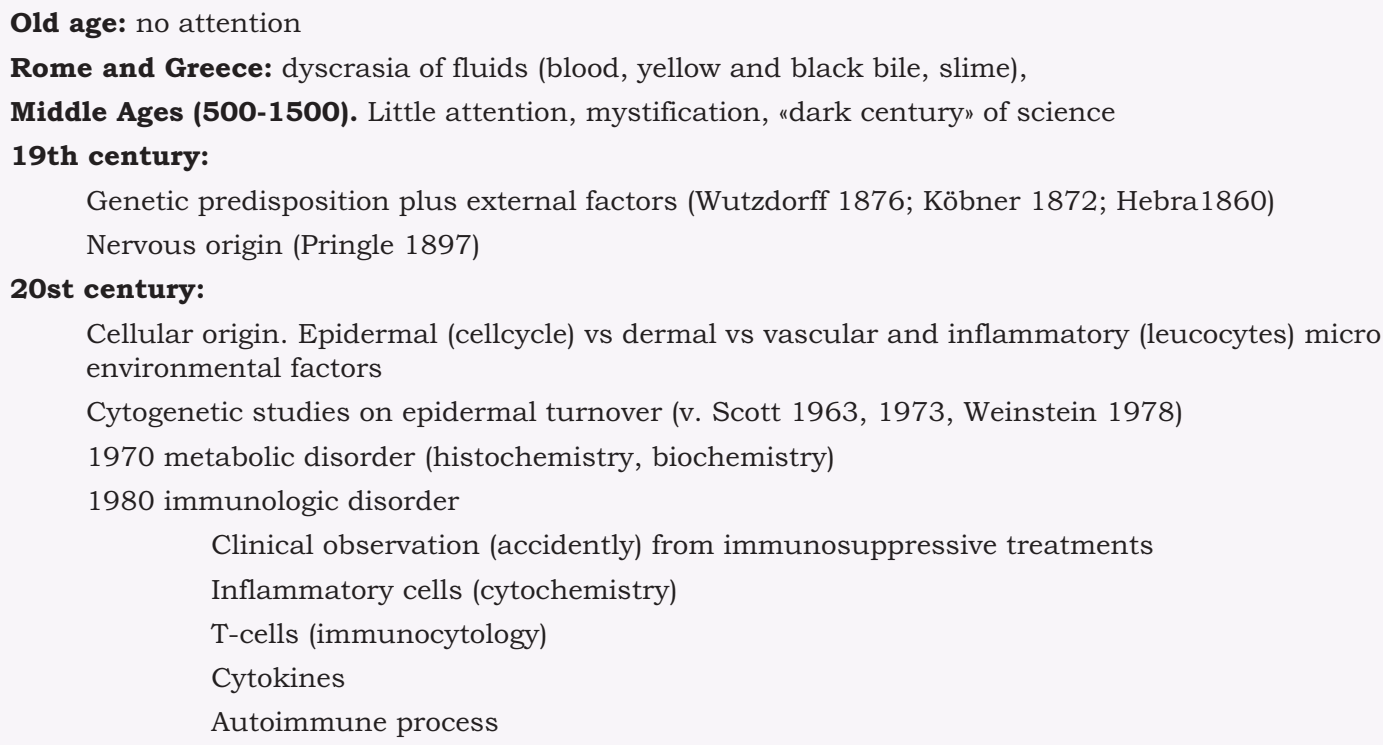

Today there is significant evidence, that the immune system plays an important role in the pathogenesis of psoriasis [Table 4].

Evidence for the immunologic background also came from accidental clinical observations or from clinical studies, in which patients with psoriasis responded well to cytostatic or immunosuppressive drugs [36].

Looking for some review articles on psoriasis during the past 20 years, the following citations in some way reflect the step by step progress in our understanding of this multifaceted disease:
* 1995: "Recently, progress has been made in understanding the pathogenesis of psoriasis... There is at present no cure, only suppressive therapy... The presumptive involvement of $\mathrm{T}$ cells in psoriasis is leading to intense interest in immunotherapy... and in identifying the genes (PSOR1)... In the future, psoriasis may be amenable to gene therapy." [37].

* 1999: "Therapies for psoriasis ... tend to have a remittent effect (inducing long-term remission) or a suppressive effect (improving

Table 4. Role of the Immune System in the Pathogenesis of Psoriasis

Increased

Dendritic cells and IFN-alpha

T-cells

Th1-cytokines

Vascular endothelial growth factor (VEGF)

Cytokines

Therapeutic effect of PUVA

Therapeutic effectivity of immunosuppressive drugs : cyclosporine (Müller 1979; Ellis et al 1991)

and Rifampicin (Tsankov 1993,2011)

Therapeutic effectivity of anti-CD4 (Morel et 1992)

Clearing after bone marrow transplantation

Transfer from transplant donor to recipient 
lesions but with a prompt recurrence when the treatment is discontinued)" [38].

* 2005: "The most promising compounds are monoclonal antibodies, cytokines, and fusion proteins" [39].

* "Numerous other biologic agents and immune response modifiers are under development; all of them use at least one of the mechanisms mentioned above" (inhibition of $\mathrm{T}$-cell activation, depletion of pathogenic $\mathrm{T}$ cells, inhibition of leucocyte recruitment, correction of immune deviation)[39].

* 2009: "The evolution of a psoriatic lesion is based on a complex interplay between environmental and genetic factors that sets the scene for disease initiating events." [40].

* “...However, major issues remain unresolved, including the primary nature of the disease as an epithelial or immunologic disorder, the autoimmune cause of the inflammatory process, the relevance of cutaneous versus systemic factors, and the role of genetic versus environmental influences on disease initiation, progression, and response to therapy." [40].

\section{History of the Therapy of Psoriasis}

It is an unwritten law in medicine that the less understood a disease is the larger is the list of our armamentarium for therapeutic approaches, which have been recommended over the decades and centuries. This holds true also for psoriasis as summarised in [Table 5].

One of the most curious recommendations, which are mentioned in the Ebers papyrus, has been the use of excrements from cats and dogs. In the Middle Ages a concoction from snakes (Viper-broth) was applied and coal tar which in some instances still may be an appropriate remedy today and which already has been recommended by Pedanios Dioscurides (40-90 AD) from Anazarbos in Kilikien, which belongs to Turkey today. He was a Greece military physician, who served for Claudius and Nero in Rome and was one of the most famous pharmacists of the antique.

Arsenic (Asiatic pills and Fowler's solution) has been very effective in the treatment of psoriasis and other diseases, including syphilis. It has been used extensively during the $19^{\text {th }}$ and first half of the $20^{\text {st }}$ century, till the

Table 5. Selection of Therapeutic Measurements From Ancient till Modern Time

Ebers Papyrus (1500 BC): topical cats and dogs dung (faeces)

Galen: Viper-broth; Coal tar

Daniel Turner 1723: Galens remedy (boile viper-broth) and ammoniated mercury (topically)

Balmanno Squire 1876: Chrysarubin (Goa powder)

Thomas Fowler. Solution of potassium arsenite

Thomas Gridlestone 1806: Fowler's solution in psoriasis

E. Tipp 1869: sc-injection of arsenous acid

Hebra and Kaposi: "Asiatic Pills"

Roentgentherapy for psoriasis in 1900 in Europe

1933 Low fat diet

1950 Sulzberger: Corticosteroids

1970-1990 UVA and PUVA

1990's Vitamin $\mathrm{D}_{3}$

1990-2000 Immunological treatment modalities

1993, 2011 Tsankov: Rifampicin

2000 on Biologicals 
hazardous effects of this substance got obvious.

Another treatment approach which still is employed today is keeping diet. The rational for this is the observation that during World War II the incidence of psoriasis decreased [41], the biochemical composition of psoriatic scales and the high blood levels of cholesterol and other lipids in the blood in patients with psoriasis. This therapeutic approach was supported by several laboratory investigations $[42,43]$.

Glucocorticosteroids (have revolutionized therapy and early in time also have been used in Dermatology, topically and systemically, although the first reports on the topical use in psoriasis were not very enthusiastic [44].

An early description of "balneotherapy" can be found in the Old Testament (Lukas 4.27), even though we do not know which skin disease Naaman, the commander of the army of the king of Arman was suffering from (the term "Lepra" at this time covered many dermatoses and there is a risk that this text was ment as a methapher and did not describe an practical treatment at all): "...so he (Naaman) went down and dipped himself in the Jordan seven times, as the man of God (Elisha) had told him, and his flesh was restored and became clean like that of a young boy." [45].

For centuries in India chrysarobin (2-methyl dithranol), the active ingredient of Goa-powder (natural; synthetic: anthralin or cignolin) was used for the treatment of "ringworm" (dermatomycoses). The English physician Balmanno Squire in 1876 inadvertently discovered its use for psoriasis $[9,46]$.

Hippokrates and other ancient physicians treated skin diseases with pine coal tar [47]. During the first half of the 20iest century it was found to be particularly useful in psoriasis [48], either alone or in combination with light and anthralin [49].

The mode of action of anthralins and coal tar is not completely elucidated. They probably function by retardation of the altered epidermal cell kinetics.

Arsenic and mercury have been used in order to treat not only syphilis but also psoriasis. Fowler's solution containing $1 \%$ arsenic was very effective [50].
The beneficial effect of aminopterin (Methotrexat) in psoriasis has been detected accidentally when clearing in a patient treated for his rheumatoid arthritis [51]. The approval by the FDA for the use in psoriasis was given in 1972 [47].

Cyclosporine (Sandimmune) originally has been developed to prevent rejection of organ transplants. Like with methotrexate it was fortuitously found to clear psoriasis in patients being treated for severe longstanding rheumatoid arthritis [52]. In 1997 cyclosporine was FDA approved for the treatment of psoriasis [53].

Another less hazardous immunomodulator recommended recently is Rifampicin [54].

Retinoids have been used for treatment of keratosis [55]. While first generation and synthetic topical retinoids (1940ies) did not have significant antipsoriatic activity, the efficacy of second generation retinoids (1990ies), etretinate and its derivate acitretin was much better [56].

Vitamin D and its analogues also were found by chance to be beneficial in the treatment of psoriasis in a patient who received Vitamin $\mathrm{D}_{3}$ for the treatment of osteoporosis [57]. A topical form of vitamin $\mathrm{D}$ has been formulated for this indication [58].

At the end of the $19^{\text {th }}$ century first reports of UV-Light in the treatment of tuberculosis and wound healing arouse interest in phototherapy. At the same time sunlight as a natural healing force became a main pier of the arising reform movement and naturopathy [59]. The photochemotherapy (PUVA, psoralen and long wave ultraviolet light A) of psoriasis has been reviewed in an autobiographically tinged monography [5]. At least 3 roots can be followed: (1) Egypt [60]. Ammi majus or Bishop's weed has been recommended in the Ebers papyrus $\left(1^{\prime} 500 \mathrm{BC}\right)$ to be rubbed directly into the skin or taken orally and then to stand naked in the sun (2) Europe. There have been experiments in Switzerland with selective spectra of UV-light [61]. In Germany studies with topical photosensitizers have been performed $[\mathbf{6 2}, \mathbf{6 3}]$. In Austria methoxsalen was applied orally [64], following successful studies in (3) the United States [65].

A very special and regional approach to the therapy of psoriasis is bathing with fishes from Sivas-Kangal [66]. 


\begin{tabular}{|c|c|c|c|c|c|c|c|}
\hline $19^{\text {th }} \mathrm{C}$ & $1900-1930$ & $1930-1950$ & $1950 \mathrm{~s}$ & $1960 \mathrm{~s}$ & $1970 \mathrm{~s}$ & $1980 \mathrm{~s}$ & $1990-21^{11} \mathrm{C}$ \\
\hline \multicolumn{8}{|l|}{ Arsenic } \\
\hline \multicolumn{8}{|l|}{ Mercury } \\
\hline Chrysarobin & Anthralin & & & & & & \\
\hline \multicolumn{8}{|l|}{ Coal Tar } \\
\hline \multicolumn{8}{|l|}{ Salicylic } \\
\hline & X-Rays & & & & & & \\
\hline & Radium & & & & & & \\
\hline & Grenzrays & & & & & & \\
\hline & Phototherapy & & & & & & \\
\hline & Goeckerman & & & & & & \\
\hline & & Ingram & & & & & \\
\hline & & Vitamin D & & & & & \\
\hline & & & Steroids & & Top. Steroids & & \\
\hline & & & Aminopterin & & & & \\
\hline & & & Methotrexate & & & & \\
\hline & & & & Hydroxyurea & & & \\
\hline & & & & Top. Retin.Ac & & & \\
\hline & & & & & Photochemo & & \\
\hline & & greens & & & Climatoth. & & \\
\hline & & & & & & Vit. D Analogs & \\
\hline & & End") Therapies & & & & Etretinate & \\
\hline & Eve & eens & & & & N-Band UVB & \\
\hline & & & & & & Cyclosporin & \\
\hline & & & & & & & Biologicals \\
\hline & & & & & & & Laser \\
\hline & & & & & & & Tacrolimus \\
\hline & & & & & & & Top. Ascomycin \\
\hline & & & & & & & Rifampicin \\
\hline & & & & & & & Tazarotene \\
\hline
\end{tabular}

Figure 6. Historical view on evergreens, nevergreens and "dead end" therapies in psoriasis (not comprehensive)

An early immunologic approach to the treatment of psoriasis was with monoclonal antibodies [67]. The mode of action was considered to be different from the pathway in photochemotherapy: "We conclude that anti-CD4 $\mathrm{mAb}$ administration can induce a rapid and major improvement in psoriatic lesions (.. of 3 patients with severe psoriasis...), with immunohistochemical changes different from those induced by cyclosporin A or 8methoxypsoralen plus long wave UV light (PUVA) therapy. Our data provide strong evi- dence for a critical role of $\mathrm{CD}^{+}$lymphocytes in psoriasis" [67].

Clinical observations and laboratory investigations of the past decade have pointed to the fact, that psoriasis is a T helper (Th) $17 /$ Th 1 mediated autoimmune disease affecting the skin and joints [40]. Based on the understanding of the immunologic processes, several substances for a targeted therapy have been developed (Biologicals) [68] and have been approved by the FDA in 2003 for the treatment of psoriasis [57].

Table 6. Celebrities, Who Possibly have Suffered from Psoriasis

\begin{tabular}{l} 
Artist \\
Zarah Leander \\
Poets \\
John Updike* \\
Dennis Potter** \\
Revolutionizer \\
Jean Paul Marat*** \\
Politicians \\
Josef Stalin \\
Winston Churchill \\
* Report on the treatment with retinoids, Methotrexate and light in the book "Self-consciousness: Memoirs", 1976 \\
$* *$ Movie: The singing Detective (trailer: http://www.youtube.com/watch?v=wwwhtUdGOVM) \\
*** Suffered possibly from chronic eczema (neurodermatitis) \\
\hline
\end{tabular}


Table 7. History of Psoriasis. Milestones and Protagonists

Old Age: Ignorance no scientific basis, skin rash and impurity, punishment by God

Greece: Neglectance, Hippocrates (460-377): psora= itch

Roman Empire $1^{\text {st }}$ Century: lack of consistent terms and nomenclature Cornelius Celsus (25 BC-50): first description of psoriasis

Galen (131-201 AD): first use of the term psoriasis (probably for seborrhoeic dermatitis)

Middle Age (500-1500): Neglectance, clerical mysticism. "Dark" age for Science

Arabian Medicine (Avicenna 980-1037)

Early $18^{\text {th }}$ Century: "Protodermatologists"

Charles Anne Lorry (1726-1783): "Tractatus de morbis cutaneis".

Joseph Jacob Plenck (1738-1807): Surgeon and obstetrician. Term Impetigo (Latin "atack")

Late18th Century: "Dermatologists": Nosologic Descriptions

Robert Willan (1757-1812): differentiation between psora leprosa and psora grecorum

Jean Louis Alibert (1768-1837): Psoriasis in the group of "dartrous dermatoses "

Early $19^{\text {th }}$ Century: Nosologic definitions, impact of histopathology

Ferdinand Hebra (1806-1880): definitely separated psoriasis from leprosy; histopathology

Heinrich Auspitz (1835-1886): histopathology; sign already seen by Willan and Hebra

Ernest Henri Besnier (1831-1909): Histopathology; term "arthritis psoriatica"

William John Munro (1861-1908): Microabscess (1898)

Paul Gerson Unna (1850-1929): Histopathology; Micrococci

Late $1^{\text {th }}$ and early 20 ${ }^{\text {st }}$ Century: Description of Variants of Psoriasis

Leo von Zumbusch (1884-1940): Psoriasis pustularis 1910

Königsbeck (1917), Barber (1936): Psoriasis pustulosa palmoplantaris

Heinrich Köbner (1838-1904): isomorphous effect of irritation

$D L$ Woronoff (1926): rings around lesions in psoriasis and in corymbiform syphilis

20 $^{\text {st }}$ Century: Biochemistry, Histochemistry, Cytogenetics, PASI, Biologics

Carbohydrate Metabolism in psoriatic epidermis (Halprim, Vorhees, Rassner, Braun-Falco)

Epidermal turnover: van Scott, EJ, 1963,1973; Weinstein 1968

Multifactorial: different chromosomes (PSOR1-PSOR9)

HLA-association;Type 1 and Type 2 (Henseler and Christophers 1985)

PASI 1972 (Fredriksson and Pettersson)

Treatment with Biologics, anti CD4 1992

$21^{\text {st }}$ Century: Genetics, Immunology, Autoimmunity, Targeted Therapy (Biologics)

Mode of inheritance: chromosomal loci with linkage to psoriasis (PSOR1(Chr 6p)-PSOR9)

Dendritic cells and T-cells, type I interferons

Dysregulated immune system in psoriasis; role of plasmacytoid dendritic cells, IFN- $\alpha$

Antimicrobial peptides from keratinocytes: defensin, psoriasin (Schroeder)

Alteration of the innate and adaptive immune response in psoriasis

Targeted therapy with biologics

Future Issues: Safety, Economics; Controlled Studies; Psoriasis-Registries

The many substances and procedures recommended or used for the treatment of psoriasis roughly can be designated as evergreens (successful use up today), "nevergreens" (anecdotic reports) and obsolete (including hazardous substances like arsenic or mercury) (Figure 6). This review is not comprehensive and many issues are missing.

\section{Famous Persons Suffering from Psoriasis}

Psoriasis is one of the most frequent dermatoses, affecting about $2 \%$ of the population, including average people and celebrities, among them artists, poets, revolutionizer, politicians, and others. Most of them tried to hide their disease. Only Dennis Potter very frankly presented the psychological distress of his disease in the 
movie "The Singing Detective" (trailer: http: / / www.youtube.com/watch?v=wwwhtUdGOVM).

An incomplete list of famous persons suffering from psoriasis is given in [Table 6].

\section{Timeline of Psoriasis through the Ages}

The time line over the centuries reflects a cloudy image which has to be seen in the context of the perception of diseases in the respective time periods [Table 7].

There was ignorance no scientific basis on the nature of the disease in ancient time and confusion lack of consistent terms and nomenclature still through the Middle Ages. For the first time, Lorry in France and Plenck in Austria, subsequently Alibert and Willan payed more attention to the disease and defined it as a nosologic entity, which finally was labelled with the term "psoriasis vulgaris" by Hebra. Many important contributions on the histopathologic changes came from Hebra, Auspitz, Besnier, Munro, Unna, Kogoj and others in the late 19th and early 20st century. During the same time, some clinical variants of psoriasis were described. Studies on psoriasis in the 20st century were driven by new laboratory technologies (biochemistry, histochemistry, immunohistochemistry), which all generated some interesting results and figures, however without elucidating the basic pathogenetic nature of the disease. Only the last decade of the past and the first decade of the $21^{\text {st }}$ century shed some light on the complex genetically predetermined and immunologically driven systemic disease with its major manifestation on the skin. These new insights into the pathogenetic processes facilitated the development of targeted biologic therapies. Since the new therapeutics are extremely expensive and also imply some threats and side effects, a pivotal challenge for the future will be controlled clinical studies on safety, efficiency and economic accountability and collection of data in "psoriasis registries".

\section{Acknowledgement}

This paper is based on an oral presentation given during the $2^{\text {nd }}$ Congress on Psoriasis in Istanbul, $8^{\text {th }}$ March, 2014. Even though extensive and thorough studies of the literature were undertaken, they were not completely comprehensive and due to the obscure profiles of the disease-descriptions in the pre-diagnostic era, some of the conclusions drawn and statements made in this article have to remain speculative in many respects and are not necessarily historically authentic.

\section{References}

1. Bechet PE. Psoriasis. A brief historical review. Arch Dermato Syphilol 1936: 327-334.

2. Baker BS. From Arsenic to Biologicals: A 200 year of Psoriasis 2008, Beckenham UK: Garner Press.

3. E, B. A Practical Treatise on Lepra Vulgaris with Cases 1834: County Press.

4. Holubar K. Psoriasis--100 years ago. Dermatologica 1990; 180: 1-4. PMID: 1968402

5. Saalmann G and Schlange-Schöningen G. Die Psoriasis. Geschichte und Therapie vom Altertum bis zur Gegenwart 1998, Herford: G. Saalmann.

6. Articles, S.I.s.a.a., Current State on Psoriasis and Naphthalanotherapy. Acta Dermatovenerol Croat 2004. 12

7. O'Daly J. Psoriasis. In: A Systemic Disease. O'Daly J, Editor 2012 , http: / /www.intechopen.com/books/psoriasis-asystemic- disease/psoriasis-history-definition-and-treatment-through-centuries

8. Porter R. Die Kunst des Heilens. Eine medizinische Geschichte der Menschheit von der Antike bis heute 2000, Heidelberg, Berlin: Spektrum Akademischer Verlag.

9. Brajac I and Gruber F. History of Psoriasis. In: Psoriasis-A Systemic Disease, O’Daly J, Editor. 2012, INTECH. 57-68.

10. Bol F. The Director of the Lepra House in Amsterdam, 1616-1680: Petit Palais, Paris.

11. Plenck JJ. Doctrina de Morbis Cutaneis 1776, Wien: Rudolph Gräffer.

12. Willan R and Bateman T. A Practical Synopsis of Cutaneous Diseases 1813, London.

13. Lorry, Tractatus de Morbis Cutaneis 1777.

14. Rook A. Edward Beck's Treatise on lepra vulgaris (1834). Med Hist 1957; 1: 160-167. PMID: 13417898

15. Hebra F.v. Über die Krätze. Med Jb, 1844; 280-292.

16. Pringle J. A Pictorial Atlas of Skin Diseases and Syphilitic Affections 1897, London, Philadelphia: Rebman, Saunders.

17. Zumbusch von L. Psoriasis and pustuloses exanthem. Arch Derm Syph 1910; 99: 335-346.

18. Khan SA, Peterkin GA, Mitchell PC. Juvenile generalized pustular psoriasis. A report of five cases and a review of the literature. Arch Dermatol 1972; 105: 6772. PMID: 4400368 
19. Andrews GW, Birkman FW and K.J. R, Recalcitrant pustular eruptions of the palms and soles. Arch Dermatol Syphilol 1934: p. 548-558.

20. Barber H. Acrodermatitis Continua vel Perstans (Dermatitis Repens) and Psoriasis Pustulosa. Brit J Dermat 1930; 42: 500 .

21. Köbner H. Fallpräsentation, 1872.

22. Köbner H. Zur Aetiologie der Psoriasis. Vjschr Dermatol 1876; 8: 559-561.

23. Kuner N, Hartschuh W, Khan-Durani B. Heinrich Köbner and the "isomorphic phenomenon". History and review of the literature]. Hautarzt 2003; 54: 274 278. PMID: 12634998

24. Unna, P., Die Histopathologie der Hautkrankheiten 1894, Berlin: August Hirschwald.

25. Kraus, A., Über das Wesen des sogenannten Unnaschen Flaschenbazillus. Archiv für Dermatologie und Syphilis 1913; 116(3): 723-736.

26. Meirowsky E. Über das Wesen der Unnaschen Flaschenbazillen und über den feineren Bau einiger Hautpilze. Archiv für Dermatologie und Syphilis 1911; 108: 129-140.

27. Munro W. Note sur L'histopathologie du Psoriasis. Ann Dermatol Syph 1898; 9: 961-967.

28. Woronoff D. Die peripheren Veranderungen der Haut um die Effloreszenzen der Psoriasis vulgaris und Syphilis corymbosa. Derm Wschr 1926; 82: 249-258.

29. Wutzdorff E. Beiträge zur Aetiologie der Psoriasis vulgaris. Vjschr Dermatol 1876; 8: 329-349.

30. Christophers E, Kiene P. Guttate and plaque psoriasis. Dermatol Clin 1995; 13: 751-756. PMID: 8785880

31. Elder JT, Nair RP, Guo SW, Henseler T, Christophers E, Voorhees JJ. The genetics of psoriasis. Arch Dermatol 1994; 130: 216-224. PMID: 8304761

32. Vanscott EJ, Ekel TM. Kinetics of hyperplasia in Psoriasis. Arch Dermatol 1963; 88: 373-381. PMID: 14051348

33. Weinstein GD, Frost P. Abnormal cell proliferation in psoriasis. J Invest Dermatol 1968; 50: 254-259. PMID: 5644899

34. Braun-Falco O, Burg G. Inflammatory infiltrate in psoriasis vulgaris. A cytochemical study. Arch Klin Exp Dermatol 1970; 236: 297-314. PMID: 5438728

35. Braun-Falco O, Burg G. Histochemistry of capillaries in psoriasis vulgaris. Arch Klin Exp Dermatol 1970; 236: 173-189. PMID: 4312561

36. Ellis CN, Fradin MS, Messana JM, Brown MD, Siegel MT, Hartley AH, Rocher LL, Wheeler S, Hamilton TA, Parish TG, et al. Cyclosporine for plaque-type psoriasis. Results of a multidose, double-blind trial. N Engl J Med 1991; 324: 277-284. PMID: 1986287

37. Greaves MW, Weinstein GD. Treatment of psoriasis. N Engl J Med 1995; 332: 581-588. PMID: 7838193

38. Robert C, Kupper TS. Inflammatory skin diseases, T cells, and immune surveillance. N Engl J Med 1999; 341: 1817-1828. PMID: 10588968

39. Schön MP, Boehncke WH. Psoriasis. N Engl J Med 2005; 352: 1899-1912. PMID: 15872205
40. Nestle FO, Kaplan DH, Barker J. Psoriasis. N Engl J Med 2009; 361: 496-509. PMID: 19641206

41. Engelhardt W, Cordes W. Der Einfluss der Kriegsund Nachkriegszeit auf Psoriasis und Hauttuberkulose. Dermatologische Zeitschr 1935; 70: 321-327.

42. Grütz O, Bürger M. Die Psoriasis als Stoffwechselproblem. Klinische Wochenschrift 1933; 12: 273279.

43. Behrman H. Undecylenic acid in psoriasis. JAMA 1949; 141: 407.

44. Sulzberger MB, Witten VH. The effect of topically applied compound $F$ in selected dermatoses. J Invest Dermatol 1952; 19: 101-102. PMID: 14955641

45. Meffert H, Rowe E. Psoriasis-Politik-Kunst-ModeKrankheitsbürde-Lebensqualität, in Kleine Kulturgeschichte der Haut, E. Jung, Editor 2007, Steinkopff: Darmstadt. 84-94.

46. Squire B. On the treatment of psoriasis by an ointment of chrysophanic acid 1878, London: Churchill.

47. Weinberg J. Treatment of Psoriasis. Milestones in Drug Therapy. Parnham M, Bruinvels J eds. 2008, Basel-Boston-Berlin: Birkhäuser.

48. Goeckerman W. Treatment of psoriasis. North West Med 1925; 24: 229-231.

49. Ingram JT. The approach to psoriasis. Br Med J 1953; 2: 591-594. PMID: 13082048

50. Gridlestone T. Observations on the effects of Dr. Fowler's solution in lepra and other diseases. Med Phys J London, 1806; 15: 298-301.

51. Gubner R, August S, Ginsberg V. Therapeutic suppression of tissue reactivity. II. Effect of aminopterin in rheumatoid arthritis and psoriasis. Am J Med Sci 1951; 221: 176-182. PMID: 14799481

52. Mueller W, Herrmann B. Cyclosporin A for psoriasis. $\mathrm{N}$ Engl J Med 1979; 301: 555. PubMed PMID: 460314.

53. Prodanovic E, Korman N. Traditional systemic therapy I: methotrexate and cyclosporine, in Treatment of Psoriasis. Weinberg JM, Editor, 2008, Birkhäuser: Switzerland. 103-120.

54. Tsankov N, Grozdev I. Rifampicin--a mild immunosuppressive agent for psoriasis. J Dermatolog Treat 2011; 22: 62-64. PMID: 20653488

55. Stüttgen G. Zur Lokal behandlung von keratosen mit Vitamin A-Säure. Dermatologica 1962; 124: 65-80.

56. Ward A, Brogden RN, Heel RC, et al. Isotretinoin. A review of its pharmacological properties and therapeutic efficacy in acne and other skin disorders. Drugs 1984; 28: 6-37.

57. Cowden A, Van Voorhees A. Introduction: History of psoriasis and psoriasis therapy, in Treatment of Psoriasis, Weinberg J, Editor, 2008, Birckhäuser: Switzerland. 1-9.

58. Kragballe K, Beck HI, Søgaard H. Improvement of psoriasis by a topical vitamin D3 analogue (MC 903) in a double-blind study. Br J Dermatol 1988; 119: 223-230. PMID: 3048369

59. Geiges M. "Und am höchsten das Licht". In: Heilotherapie in der Schweiz. Die schwiez als Kraftraum und Sanatorium. Graf F, Wolff E, eds. 2010: Baden. 111-121. 
60. El Mofty A. A preliminary report on the treatment of leukoderma with Ammi majus Linn. J R Egypt Med Assoc, 1948; 31: 651-655.

61. Kuske H, Perkutane Photosensibilisierung durch pflanzliche Wirkstoffe. Dermatologica 1940; 82: 273338.

62. Mortazawi S. Meladinine mit UVA bei Vitiligo, Psoriasis, Parapsoriasis und Akne vulgaris. Dermatol Wochenschr 1972; 158: 908-911.

63. Tronnier H, Schuele D. First results of therapy with longwave UV after photosensibilisation of skin in Progress in Photobiology. Proceedings of the VI Internat 1972 Congress on Photobiology. Bochum, G. Schenck, Editor 1972.

64. Wolff K, Hönigsmann H, Gschnait F, Konrad K. Photochemotherapy of psoriasis: Clinical experiences with 152 patients (author's transl). Dtsch Med Woc- henschr 1975; 100: 2471-2477. 1497. PMID: 1201723

65. Parrish JA, Fitzpatrick TB, Tanenbaum L, Pathak MA. Photochemotherapy of psoriasis with oral methoxsalen and longwave ultraviolet light. N Engl J Med 1974; 291: 1207-1211. PMID: 4422691

66. Ozçelik S, Polat HH, Akyol M, Yalçin AN, Ozçelik D, Marufihah M. Kangal hot spring with fish and psoriasis treatment. J Dermatol 2000; 27: 386-390. PMID: 10920584

67. Morel P, Revillard JP, Nicolas JF, Wijdenes J, Rizova $\mathrm{H}$, Thivolet J. Anti-CD4 monoclonal antibody therapy in severe psoriasis. J Autoimmun 1992; 5: 465-477. PMID: 1384529

68. Belge K, Brück J, Ghoreschi K. Advances in treating psoriasis. F1000 Prime Rep 2014; 6: 4. PubMed PMID: 24592316 